\title{
The effect of leadership style and IT support on lecturer performance during e-learning program with work environment as mediating variable
}

\author{
Awanis Linati Haziroh*, Febrianur Ibnu Fitroh Sukono Putra, \\ Risanda Alirastra Budiantoro \\ Department of Management, Faculty of Business \& Economics, Universitas Dian Nuswantoro, \\ Semarang, Indonesia
}

\begin{abstract}
Article History
Received : 10 July 2021

Revised : 21 August 2021

Accepted : 26 August 2021

Published : 27 August 2021

Keywords:

Information technology support, leadership style, lecturer performance, work environment, and e-learning program.
\end{abstract}

\section{*Corresponding author:} awanislinati@dsn.dinus.ac.id

DOI:

10.20885/AMBR.vol1.iss2.art4

\begin{abstract}
The lecturer performance appraisal system is the work of lecturers within the scope of their responsibilities which refers to a formal and structured system used as an instrument to measure, assess, and influence work-related traits, control lecturer behavior, including absenteeism rates and work results. Lecturer professionalism must, of course, be related and built through mastery of fundamental competencies in carrying out and completing their duties and work as lecturers, such as professional competence, social competence, and personal competence. The low performance of lecturers is suspect of having reasons such as lack of attention and concern from leaders, for example, less effective leadership styles, less communicative work relationships, lack of harmony, lack of welfare, lack of motivation, lack of a comfortable work environment, and lack of satisfaction felt by the lecturers. Based on these reasons, further research is needed on the influence of leadership style and work environment on lecturer performance in carrying out the teaching and learning process at private universities in Semarang. This research is a quantitative study with a sample of 127 permanent lecturers in the management department of private universities in Semarang. The analytical technique used in this study is path analysis with the results. Among others, leadership style, information technology support, and work environment significantly affect lecturer performance. Furthermore, the work environment can mediate the relationship between leadership style and information technology support on lecturer performance.
\end{abstract}

\section{Introduction}

The social competence in the field of relations and services, community service. The personal competence, The performance of lecturers (teaching staff) is influenced by several factors related to the workforce and those related to the company or organization environment, such as leadership style, organizational support, and work environment (Mulyaningsih et al., 2020). The main factor causing the low quality of education is the condition of teachers, namely their qualifications are not appropriate, or teaching is not following their field of expertise. Challenges related to the quality of educators include personal challenges, personal competence, and the skills of educators in carrying out their duties. Lecturer performance is measured based on the lecturer's workload, including main activities, namely planning to learn, carrying out the learning process, evaluating learning, guiding and training, conducting research, doing community service, and performing additional tasks (Fawehinmi et al., 2020).

The low performance of the lecturers is inseparable from the lack of leadership roles in the management of the tri dharma of higher education which should have more significant results (Handayani, 2019). Another impact of the low performance of lecturers is affecting the reputation 
and image of private universities in Semarang because research and community service are some of the critical factors in increasing the competitiveness of a university in the education industry which shows that the lecturers have proven expertise. Rewards for teaching are following the credits taught and additional transportation according to the number of attendance (Tahir et al., 2018). In regular or online classes, lecturers still get total salaries and available allowances for lecturer positions. In the implementation of teaching evaluation, lecturers get rewards for making questions, corrections, supervision, and other allowances. The lecturer's performance assessment results in the implementation of the teaching and learning process so far are based on the number of lecturers' attendance in the journal, and feedback is given to all lecturers. The teaching and learning process evaluation meeting is only held at the end of the semester and at the same time facing the new school year (Harni, 2018).

During the Work From Home (WFH) period, all levels of education from primary to higher education need to strengthen online learning. One of them is students who are more focused on learning when attended directly and listening to lecturers' explanations have changed because they have to be carried out online. Even though the teaching facilities are complete and sophisticated, if it is not supported by lecturers who perform well, it is impossible to lead to a maximum learning process. Higher education in Semarang lies in the relatively ineffective means of presenting lectures because, before teaching, the lecturer prepares handouts or diktats that are not following the conditions of lectures using the online method. The effectiveness of lecturer delivery methods in teaching is also generally still relatively low because they are not familiar with online learning methods, so it is necessary to adapt to the sophistication of the technology used. The development of lecturers' learning motivation for students is also not following the predetermined planning because the role of the lecturer becomes insignificant due to the meetings being held only online (Sukirno, 2020).

The research conducted by Birbirsa \& Lakew (2020) shows that the leadership style supported by the availability of information technology has a significant effect on performance, while research conducted by Soetikno (2017) shows that leadership style has no significant effect on performance. Performance. Research conducted by Naujokaitiene et al. (2015) shows a positive and significant effect of information technology support on improving employee performance. This situation is contrary to Bozkurt et al. (2015) research, which shows no influence of information technology support variables on improving employee performance. Research conducted by Sun (2019) shows a positive and significant effect of the work environment on employee performance. This result contradicts Wilson (2016) research, which shows no influence of work environment variables on employee performance. This research was conducted comprehensively to obtain benefits for higher education performance in private universities in Semarang.

So the urgency in this research is to contribute knowledge or advice to the management of private higher education organizations in Semarang in order to improve the performance of lecturers in the teaching and learning process during work from home, improve the quality and quantity of research, and optimize community partnership programs. In addition, the urgency of this research is to study effective schemes to measure or assess lecturer performance based on leadership style and work environment in the teaching and learning process during work from home, improve the quality and quantity of research, and optimize community partnership programs. Therefore, a paradigm shift is needed, especially a change in leadership patterns that will be the key to the success of an organization. This background shows that there are problems in the performance of lecturers in carrying out the teaching and learning process at private universities in Semarang online. Based on these reasons, further research needs to be done on the influence of leadership style and work environment on the performance of lecturers in carrying out the teaching and learning process at private universities in Semarang.

\section{Literature Review and Hypotheses Development}

\section{Lecturer Performance}

Lecturer performance is often interpreted as the achievement of tasks, where lecturers in their work 
must follow the organization's work program to show the level of organizational performance in achieving the organization's vision, mission, and goals. Factors that affect lecturers' performance are the lecturer's ability for the job, the level of effort devoted, and the organizational support he receives. Lecturer performance is reduced if one of these factors is reduced or absent (Bos-Nehles et al., 2017). Performance can be defined as the work achieved by a person in carrying out the assigned tasks and responsibilities (Bungai \& Perdana, 2018). Differences in individual characteristics can cause different work performance or, in this case, their performance if faced in different situations. In addition, the same person can produce different performances in different work situations. All of this explains that performance is influenced by two things, namely: individual factors and situational factors (Aropah et al., 2020).

\section{Work From Home}

The changes in the organization in assigning duties and responsibilities to lecturers by "forbidding" lecturers to work in the office and gather in the room, so that lecturers have to work at home, this is called work from home (WFH). Currently, WFH is a strategy adopted by many organizations and provides many benefits for organizations, including educational institutions (Putra et al., 2020). It is said that the application of WFH in Indonesia is not due to organizations that work from their original culture or method, but to reduce the spread of Covid-19, so that decision making by managers must implement WFH to maintain lecturer productivity. For some informants who have access to a place to live far away, WFH is ideal for maintaining productivity because of the significant reduction in transportation costs and time. Companies that support work from home claim that this last opportunity results in greater productivity (Purwanto et al., 2020).

Indicators of work from home include the work environment, stress disorders, proximity to family, travel time, health and work balance, creativity, and high productivity. The work environment allows employees to make their own choices regarding engaging in tasks related to their work. Stress disorders can be caused by stimuli that turn out to be severe and prolonged so that a person is challenging to deal with and usually arises because of life problems and daily disturbances. The role of the family is essential for a person to support all his activities and activities. Travel time is the time it takes to cover a certain distance. Maintaining health and work balance for an individual is essential and must be considered to obtain maximum work results. Creativity is needed to provide ideas in problem-solving consistently and separate home and office work and self-pressure (Hadiantini et al., 2017).

\section{Distance Learning Program}

Distance education teaches students to learn separately from educators and their learning using the internet and online learning resources according to information and communication technology and with the help of sophisticated media. This situation follows the contents of Law number 20 of 2003 article 1 paragraph 15, which states, "Distance education is education in which students are separated from educators and learning uses various learning resources through communication technology, information, and other media" (Yulia, 2020) Some characteristics of distance education include the separation of learning that approaches a permanent element between teaching staff and students during the education program, the separation between one student and other students during the education program, the existence of an institution that manages the educational program, the use of communication facilities. Good mechanics as learning materials, providing two-way communication facilities so that students can take dialogue initiatives and seek and process the benefits (Hamid et al., 2020).

Distance learning usually uses applications in the e-learning-based learning process that begins with a plan. The planning process becomes a plan description (scenario) regarding several activities and actions carried out before learning or during the guidance process (Huang, 2020). In e-learning learning, planning includes plans, estimates, and an overview of learning system activities that utilize computer network resources properly. Next is the implementation stage, in which, of course, there are procedural e-learning implementation models that can be used, such as the selective model, then the sequential model, the static station model, and the laboratory model. The 
third stage is the evaluation used to measure the extent to which the e-learning learning objectives have been achieved or not (El Firdoussi et al., 2020).

\section{Leadership Style}

Leadership is divided into two concepts, namely, as a process and as an attribute. As a process, leaders are focused on what their leaders do, namely how leaders use their influence to clarify the organization. As for the attributes, leadership is a collection of characteristics that a manager must possess. Leadership is someone who can influence the behavior of others without using force so that the people they lead accept themselves as worthy of leading them (Anyango, 2015).

Leadership style is a set of characteristics used by leaders to influence subordinates so that goals are achieved, or leadership style is a pattern of behavior and strategies that are preferred and often applied by a leader. The leadership style is distinguished, among others, by the charismatic leadership style that can attract the attention of many people due to various factors possessed by a leader who is a gift from God. The advantage of this charismatic leadership style is that it attracts people. They were fascinated by his uplifting way of speaking. Authoritarian leadership style is a style of leader who concentrates all decisions and policies taken from himself fully. In an authoritarian leadership style, the leader controls all aspects of the activity. Democratic leadership style is a style of leader who gives broad authority to subordinates. Whenever there is a problem, always involve subordinates as a complete team. In a democratic leadership style, the leader provides much information about the duties and responsibilities of his subordinates (Babatunde, 2015).

\section{Information Technology Support}

Information Technology Support assures that employees will be rewarded for the results of taking good action, and at the same time, the organization has a high level of tolerance for mistakes. Take those that provide a greater potential return for the organization at the expense of a greater probability of failure. It is recommended that subordinates and their superiors have higher Information technology support to display a higher level of trust associated with failure (Naujokaitiene et al., 2015). Information technology support initiates a social exchange process in which employees feel obligated to help the organization achieve its goals and objectives and expect increased effort on behalf of the organization to result in greater rewards. Information technology support also satisfies social, emotional needs, resulting in greater identification and commitment to the organization, an increased desire to help the organization succeed, and greater psychological well-being (Sun, 2019). The indicators used for the perception of information technology support include security at work, ease of access, availability of applications as needed, good signal stability, and a comprehensive online learning implementation system.

\section{Work Environment}

A working environment condition is good if the lecturer can carry out activities optimally, healthy, safe, and comfortable. Therefore, the determination and creation of a good work environment will significantly determine achieving organizational goals. On the other hand, if the work environment is not good, it will reduce motivation and morale and ultimately reduce lecturer performance (Frye et al., 2019). The conditions and atmosphere of a good working environment will be created by the organization's arrangement correctly and adequately to produce a good working atmosphere, especially in well-structured organizations. In contrast, a bad working atmosphere is caused by organizations that are not well structured as well (Pradhan \& Jena, 2017).

\section{Previous Research and Hypotheses Development}

The leadership style that follows the organization's goals will carry out the program that has been set and then conduct an assessment of the program's performance. This result also applies to lecturers as a part of human resources whose performance needs to be assessed based on a predetermined plan. Furthermore, in the process of succeeding in the planned program, it is 
necessary to have support from a good work environment to provide a comfortable atmosphere for lecturers so that they can contribute more optimally to campus. This research requires support from various previous studies to obtain the expected results and can be input for institutions to optimize lecturers' performance in contributing to the education industry.

Table 1. Previous Research and Formulation of Hypotheses

\begin{tabular}{|c|c|c|c|}
\hline No & $\begin{array}{c}\text { The Researcher(s) and } \\
\text { Year }\end{array}$ & Results & Hypotheses \\
\hline 2 & $\begin{array}{l}\text { (Aropah, Sarma, \& } \\
\text { Sumertajaya, 2020) } \\
\text { (Birbirsa \& Lakew, } \\
2020)\end{array}$ & $\begin{array}{l}\text { The two results in this study } \\
\text { indicate that leadership style has a } \\
\text { significant effect on lecturer } \\
\text { performance. }\end{array}$ & $\begin{array}{l}\mathrm{H}_{1} \text { : The leadership style } \\
\text { has significant effect on } \\
\text { lecturer performance. }\end{array}$ \\
\hline 3 & $\begin{array}{l}\text { (Purwanto, Asbari, } \\
\text { Fahlevi, \& Mufid, } \\
\text { 2020) }\end{array}$ & $\begin{array}{l}\text { This results explains that } \\
\text { organizational support, especially } \\
\text { the availability of technology, has a } \\
\text { very positive impact on teaching } \\
\text { staff performance. } \\
\text { This study also explains the critical } \\
\text { role of technology support from } \\
\text { institutions in online learning } \\
\text { patterns during the Covid-19 } \\
\text { pandemic. }\end{array}$ & $\begin{array}{l}\mathrm{H}_{2}: \text { The information } \\
\text { technology support has } \\
\text { significant effect on } \\
\text { lecturer performance. }\end{array}$ \\
\hline $\begin{array}{l}5 \\
6\end{array}$ & $\begin{array}{l}\text { (Wilson, 2016) } \\
\text { (Narasuci, Setiawan, \& } \\
\text { Noermijati 2018) }\end{array}$ & $\begin{array}{l}\text { The two results in this study } \\
\text { indicate that the work environment } \\
\text { has a significant effect on the } \\
\text { performance of academic lecturers } \\
\text { even though they have different } \\
\text { objects and respondents. }\end{array}$ & $\begin{array}{l}\mathrm{H}_{3}: \text { The work } \\
\text { environment has } \\
\text { significant effect on } \\
\text { lecturer performance. }\end{array}$ \\
\hline
\end{tabular}

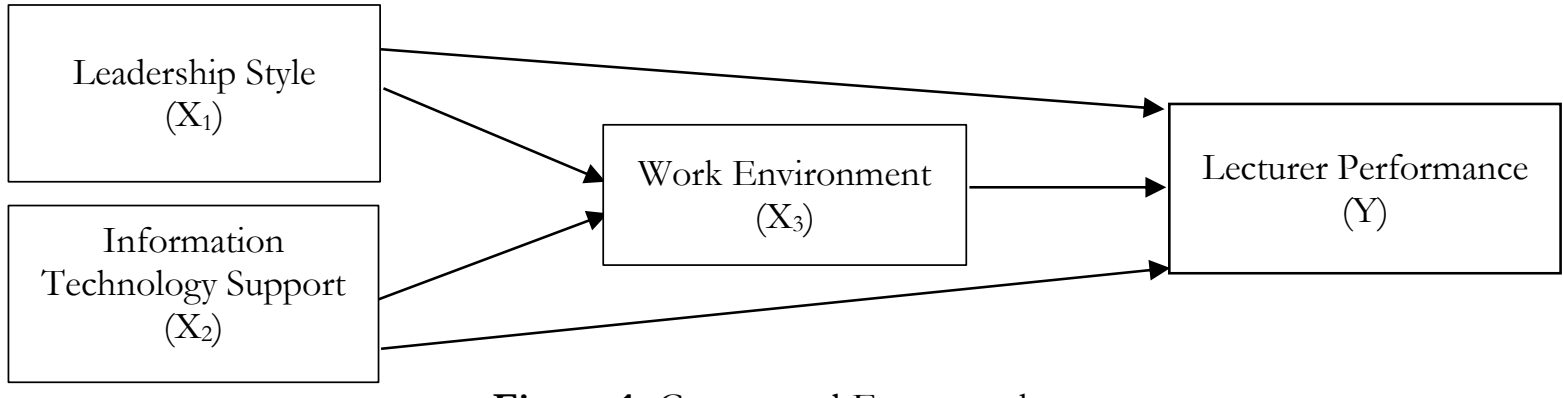

Figure 1. Conceptual Framework

\section{Research Methods}

\section{Population and Sample}

The population in this study were all permanent lecturers of the management study program totaling 259 people at 12 private universities in Semarang. The research sample was obtained through a purposive sampling technique with the criteria of respondents being permanent lecturers of the A-accredited management study program. It can be concluded that the number of respondents in this study amounted to 127 people.

\section{Path Analysis}

The analytical technique used in this research is path analysis. This analysis is used to determine the ability of the mediating variable to support the relationship between the independent variable and the dependent variable. As for the analysis results, it will be known the nature of the relationship between the two research variables, namely whether the relationship between the two variables studied shows a positive or negative relationship (Kumar et al., 2021). Path analysis in this 
study is used to measure the ability of work environment variables to mediate the influence of leadership style and information technology support on lecturer performance. The equations in this study can be arranged as follows:

Model I $-X_{3}=\alpha+\beta_{1} X_{1}+\beta_{2} X_{2}+e$

Model II $-Y=\alpha+\beta_{3} X_{3}+e$

Model III $-Y=\alpha+\beta_{1} X_{1}+\beta_{2} X_{2}+\beta_{3} X_{3}+e$

Detailed information:

$\mathrm{Y}=$ Lecturer Performance

$\mathrm{X}_{1} \quad=$ Leadership Style

$\mathrm{X}_{2} \quad=$ Information Technology Support

$\mathrm{X}_{3} \quad=$ Work Environment

$\beta_{1}, \beta_{2}, \beta_{3}=$ Regression coefficient

a $\quad=$ Constant Value

$\mathrm{e} \quad=$ Error

\section{Results and Discussion}

This study is to determine and explain the lecturer performance analysis model during e-learning program implementation.

Table 2. Result of Model I

\begin{tabular}{lcccc}
\hline \multicolumn{1}{c}{ Variables } & Coefficient Beta & Beta & $\mathrm{t}_{\text {test }}$ & sig. \\
\hline (Constant) & $-4,693$ & & $-2,047$ & 0,046 \\
Leadership Style $\left(\mathrm{X}_{1}\right)$ & 0,693 & 0,259 & 3,655 & 0,001 \\
Information Technology Support $\left(\mathrm{X}_{2}\right)$ & 0,356 & 0,126 & 2,183 & 0,033 \\
\hline $\mathrm{R}^{2} \quad=0,556$ & & & & \\
$\mathrm{~F}_{\text {test }} \quad=14,434$ (sig. 0,000) & & & & \\
\hline Source: Data processed, 2021. & &
\end{tabular}

Based on the results, the regression equation model can be arranged as follows: $X_{3}=-4,693+$ $0,693 X_{1}+0,356 X_{2}+e_{1}$

Table 3. Result of Model II

\begin{tabular}{lcccc}
\hline \multicolumn{1}{c}{ Variables } & Coefficient Beta & Beta & $\mathrm{t}_{\text {test }}$ & sig. \\
\hline (Constant) & $-0,978$ & & $-0,297$ & 0,768 \\
Leadership Style $\left(\mathrm{X}_{1}\right)$ & 0,693 & 0,669 & 2,796 & 0,004 \\
Information Technology Support $\left(\mathrm{X}_{2}\right)$ & 0,356 & 0,634 & 4,962 & 0,000 \\
\hline $\mathrm{R}^{2} \quad=0,444$ & & & & \\
$\mathrm{~F}_{\text {test }} \quad=14,758$ (sig. 0,000) & & & & \\
\hline
\end{tabular}

Source: Data processed, 2021.

Based on the results, the regression equation model can be arranged as follows: $Y=-0,978+$ $0,688 X_{1}+0,636 X_{2}+e$

Table 4. Result of Model III

\begin{tabular}{lcccc}
\hline \multicolumn{1}{c}{ Variables } & Coefficient Beta & Beta & $\mathrm{t}_{\text {test }}$ & sig. \\
\hline (Constant) & 7,966 & & 2,355 & 0,024 \\
Leadership Style $\left(\mathrm{X}_{1}\right)$ & 0,162 & 0,147 & 2,224 & 0,048 \\
Information Technology Support $\left(\mathrm{X}_{2}\right)$ & 0,504 & 0,462 & 2,638 & 0,008 \\
Work Environment $\left(\mathrm{X}_{3}\right)$ & 0,827 & 0,745 & 6,736 & 0,000 \\
\hline $\mathrm{R}^{2} \quad=0,568$ & & & & \\
$\mathrm{~F}_{\text {test }} \quad=16,625$ (sig. 0,000$)$ & & & & \\
\hline
\end{tabular}

Source: Data processed, 2021. 
Based on the results, the regression equation model can be arranged as follows: $Y=7,966+$ $0,162 X_{1}+0,504 X_{2}+e$

Table 5. Coefficient of Determination Result

\begin{tabular}{|c|c|c|c|}
\hline No & Model & $\mathbf{R}^{2}$ & $\begin{array}{l}\text { Conclusion } \\
\end{array}$ \\
\hline 1 & I & 0,556 & $\begin{array}{l}\text { The analyze results for the } \mathrm{R} \text { square value obtained } 0.556 \text { or } 55.6 \% \text {, which } \\
\text { means the independent variable can explain the variation of dependent variable } \\
\text { by } 55.6 \% \text {. }\end{array}$ \\
\hline 2 & II & 0,444 & $\begin{array}{l}\text { The analyze results for the } \mathrm{R} \text { square value obtained } 0.444 \text { or } 44.4 \% \text {, which } \\
\text { means the independent variable can explain the variation of dependent variable } \\
\text { by } 44.4 \% \text {. }\end{array}$ \\
\hline 3 & III & 0,568 & $\begin{array}{l}\text { The analyze results for the } \mathrm{R} \text { square value obtained } 0.568 \text { or } 56.8 \% \text {, which } \\
\text { means the independent variable can explain the variation of dependent variable } \\
\text { by } 56.8 \% \text {. }\end{array}$ \\
\hline
\end{tabular}

Source: Data processed, 2021.

Table 6. F-Test Result

\begin{tabular}{|c|c|c|c|}
\hline No & Model & $F_{\text {test }}$ & Conclusion \\
\hline 1 & I & $\begin{array}{c}14,434 \\
\text { (sig. } 0,000)\end{array}$ & $\begin{array}{l}\text { Based on the test, } \mathrm{F} \text { test value is } 14,434 \text { with a sig value }=0.000 \text {. This } \\
\text { shows the model used in this research is fit. The results also show the } \\
\text { independent variables simultaneously affect the work environment. }\end{array}$ \\
\hline 2 & II & $\begin{array}{c}14,758 \\
\text { (sig. } 0,000)\end{array}$ & $\begin{array}{l}\text { Based on the test, } F \text { test value is } 14,758 \text { with a sig value }=0.000 \text {. This } \\
\text { shows the model used in this research is fit. The results also show the } \\
\text { independent variables simultaneously affect the lecturer performance. }\end{array}$ \\
\hline 3 & III & $\begin{array}{c}16,625 \\
\text { (sig. } 0,000)\end{array}$ & $\begin{array}{l}\text { Based on the test, } F \text { test value is } 16,625 \text { with a sig value }=0.000 \text {. This } \\
\text { shows the model used in this research is fit. The results also show the } \\
\text { independent variables simultaneously affect the lecturer performance. }\end{array}$ \\
\hline
\end{tabular}

Source: Data processed, 2021.

Table 7. t-Test Result

\begin{tabular}{|c|c|c|c|c|c|c|}
\hline No & Model & & $\begin{array}{l}\text { Independent } \\
\text { Variables }\end{array}$ & $\begin{array}{l}\text { Dependent } \\
\text { Variable }\end{array}$ & $\mathbf{t}_{\text {test }}$ & Conclusion \\
\hline 1 & $\mathrm{I}$ & & $\begin{array}{l}\text { Leadership Style } \\
\text { Information } \\
\text { Technology } \\
\text { Support }\end{array}$ & $\begin{array}{c}\text { Work } \\
\text { Environment }\end{array}$ & $\begin{array}{c}3,655 \\
\text { (sig. } 0,001) \\
2,183 \\
\text { (sig. } 0,033)\end{array}$ & $\begin{array}{l}\text { 1. Leadership style has significant } \\
\text { effect on work environment. } \\
\text { 2. Information technology } \\
\text { support has significant effect } \\
\text { on work environment. }\end{array}$ \\
\hline 2 & II & & $\begin{array}{l}\text { Leadership Style } \\
\text { Information } \\
\text { Technology } \\
\text { Support }\end{array}$ & $\begin{array}{c}\text { Lecturer } \\
\text { Performance }\end{array}$ & $\begin{array}{c}2,796 \\
\text { (sig. } 0,004) \\
4,962 \\
\text { (sig. } 0,000)\end{array}$ & $\begin{array}{l}\text { 1. Leadership style has significant } \\
\text { effect on lecturer } \\
\text { performance. } \\
\text { 2. Information technology } \\
\text { support has significant effect } \\
\text { on lecturer performance. }\end{array}$ \\
\hline 3 & III & & $\begin{array}{l}\text { Leadership Style } \\
\text { Information } \\
\text { Technology } \\
\text { Support } \\
\text { Work } \\
\text { Environment }\end{array}$ & $\begin{array}{c}\text { Lecturer } \\
\text { Performance }\end{array}$ & $\begin{array}{c}2,224 \\
\text { (sig. } 0,048) \\
2,638 \\
\text { (sig. } 0,008) \\
6,736 \\
\text { (sig. } 0,000)\end{array}$ & $\begin{array}{l}\text { 1. Leadership style has significant } \\
\text { effect on lecturer } \\
\text { performance. } \\
\text { 2. Information technology } \\
\text { support has significant effect } \\
\text { on lecturer performance. } \\
\text { 3. Work Environment has } \\
\text { significant effect on lecturer } \\
\text { performance. }\end{array}$ \\
\hline
\end{tabular}

Source: Data processed, 2021. 


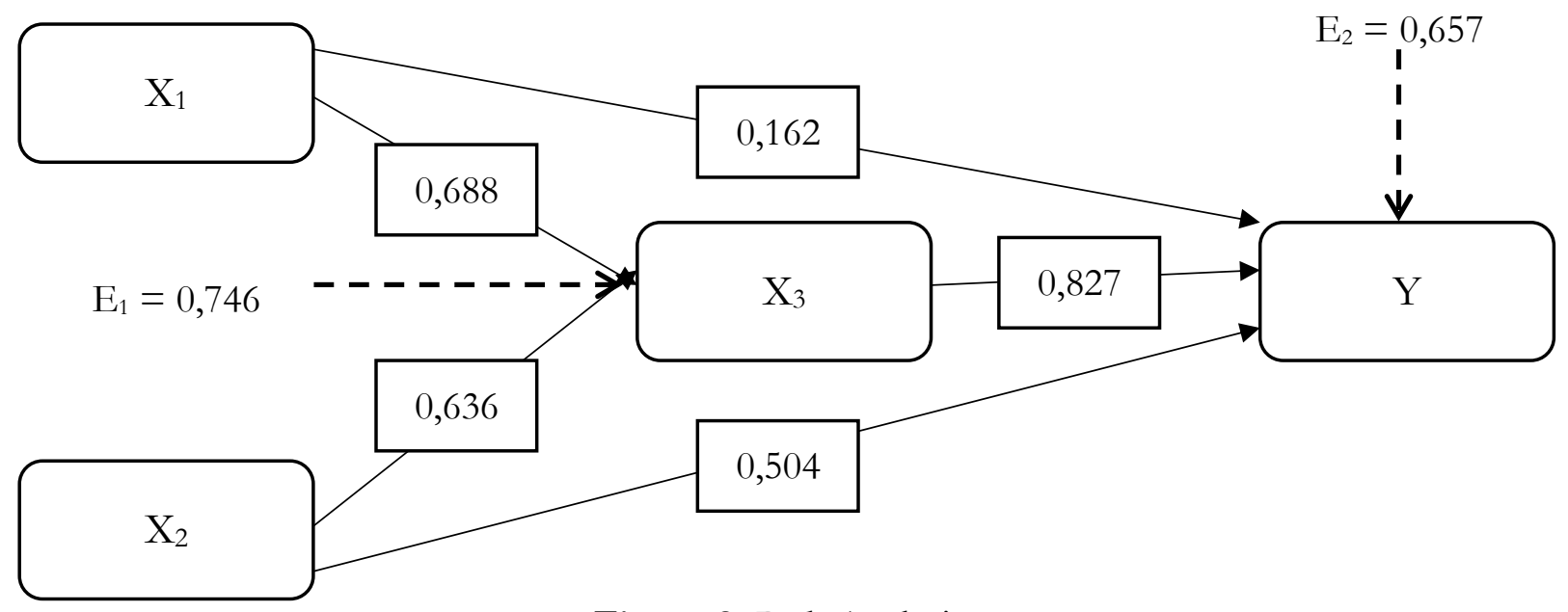

Figure 2. Path Analysis

It is known that the value of $\mathrm{R} 2$ in model $\mathrm{I}$ is 0.444 or equal to $44.4 \%$, then the standard deviation of model I is $\left(p X_{3} \varepsilon_{1}\right)=\sqrt{1-R^{2}}=\sqrt{1-0,444}=0,746$. While the value of $\mathrm{R} 2$ in model II is 0.568 or equal to $56.8 \%$, then the standard deviation of model II is $\left(p Y \varepsilon_{2}\right)=\sqrt{1-R^{2}}=$ $\sqrt{1-0,568}=0,657$.

Table 8. Result of Indirect Effect Calculation

\begin{tabular}{cccc}
\hline Independent Variable & $\begin{array}{c}\text { Mediating } \\
\text { Variable }\end{array}$ & $\begin{array}{c}\text { Dependent } \\
\text { Variable }\end{array}$ & Indirect Effect \\
\hline $\begin{array}{c}\text { Leadership Style } \\
\left(\mathrm{X}_{1}\right)\end{array}$ & $\begin{array}{c}\text { Work Environment } \\
\left(\mathrm{X}_{3}\right)\end{array}$ & $\begin{array}{c}\text { Lecturer Performance } \\
(\mathrm{Y})\end{array}$ & $0,688 \times 0,827=0,569$ \\
$\begin{array}{c}\text { Information Technology } \\
\text { Support }\left(\mathrm{X}_{2}\right)\end{array}$ & $\begin{array}{c}\text { Work Environment } \\
\left(\mathrm{X}_{3}\right)\end{array}$ & $\begin{array}{c}\text { Lecturer Performance } \\
(\mathrm{Y})\end{array}$ & $0,636 \times 0,827=0,526$ \\
\hline
\end{tabular}

Source: Data processed, 2021.

The table above shows that there is an indirect effect of leadership style (X1) on lecturer performance $(Y)$ through the work environment $(X 3)$, the value is $0,688 \times 0,827=0,569$. The result of the indirect influence is greater than the result of the direct influence of leadership style (X1) on lecturer performance $(\mathrm{Y})$ of 0.162 , so that the work environment $(\mathrm{X} 3)$ is considered capable of mediating the relationship of leadership style (X1) to lecturer performance $(\mathrm{Y})$. In addition, the indirect effect of information technology support (X2) on lecturer performance $(\mathrm{Y})$ through the work environment (X3) obtained a value of $0,636 \times 0,827=0,526$. The result of the indirect effect is greater than the result of the direct influence of information technology support (X2) on lecturer performance $(\mathrm{Y})$ of 0.504 , so that the work environment $(\mathrm{X} 3)$ is considered capable of mediating the relationship of information technology support (X2) to lecturer performance $(\mathrm{Y})$.

\section{Effect of Leadership Style on Lecturer Performance}

Based on the test results show that leadership style has a positive and significant effect on lecturer performance. The results of this study are in line with research conducted by Aropah, Sarma, \& Sumertajaya (2020) and Birbirsa \& Lakew (2020). If the leader has an ability to understand and understand the right strategy in encouraging lecturers to improve their performance, have good conceptual and innovation skills, explain and direct the tasks given, provide opportunities for lecturers to express opinions, directly supervise the performance of lecturers while working, the condition This will make a lecturer able to complete work according to standards and on time, so that later the lecturer can achieve the expected goals of the company. 


\section{Effect of Information Technology Support on Lecturer Performance}

Based on the results, information technology support has a positive and significant effect on lecturer performance. These results align with research conducted by Na-nan, Jongktrakul, \& Dhienhirun (2018) and Purwanto et al. (2018). STAI Madiun provides information technology support to its lecturers in carrying out the tri dharma of higher education because it considers the increasingly rapid development of technology, so that campus leaders consider that this can encourage lecturers to improve their performance. The suitability of work with the support of information technology provided will affect how quickly the lecturer can complete the tasks given. In addition, the ability of lecturers to utilize the technology cannot be separated from attention, where when information technology is easy to use in activities, it will further improve the performance of lecturers who in fact must be able to adapt to technological sophistication. In addition to the Integrated SIM, the lecturer will also maximize the utilization of the existing website to become a collage profile web user to access various information about campuses. This Web Profile is designed like a portal and is equipped with information access to various other campus applications (Student \& Lecturer Portal, Alumni \& Career Portal, and so on).

\section{Effect of Work Environment on Lecturer Performance}

Based on the test, the work environment has a positive and significant effect on lecturer performance. These results align with research conducted by Wilson (2016) and Narasuci, Setiawan, \& Noermijati (2018). The work environment shows how clean and comfortable the physical condition of the work organization is so that lecturers feel at home while working, a harmonious work environment between lecturers with mutual respect, and the availability of updated and renewable technological work tools will make lecturers improve their performance. It can be shown by the lecturers being able to improve their abilities and performance because they get a work environment that suits their needs. The availability of a decree from the Head of STAI Madiun regarding the academic standards of STAI Madiun states that research conducted by lecturers must support and become an integrated part of education, learning, and community service activities so that lecturers will be encouraged to maximize their performance to fulfil the tri dharma of higher education.

\section{Effect of Leadership Style on Work Environment}

The test results indicate that the leadership style has a positive and significant effect on the work environment. The results of this study are in line with research conducted by Babatunde (2015) and Soetikno (2017). If the leader has the ability to understand and understand the right strategy in encouraging lecturers to improve their performance, have good conceptual and innovation skills, explain and direct the tasks given, provide opportunities for lecturers to express opinions, supervise lecturers directly while working, then this condition will support the policy of the Head of STAI Madiun's Decree regarding the academic standards of STAI Madiun stating that research conducted by lecturers must support and become an integrated part of education, learning, and community service activities to fulfil the tri dharma of collage.

\section{Effect of Information Technology Support on Work Environment}

The test results indicate that the support of information technology has a positive and significant effect on the work environment. The results of this study are in line with research conducted by Yulia (2020). In the context of the advancement of Higher Education in managing technology and information-based management, the lecturer will maximize the Integrated Management Information System program.

As an Integrated SIM, it includes several accesses such as student registration and registration information systems, academic information systems, alumni information systems, personnel information systems, budget and financial information systems and library information systems to support lecturers to feel at home while working, a harmonious working environment between lecturers and students mutual respect. 


\section{Effect of Leadership Style on Lecturer Performance Mediated by Work Environment}

The test results indicate that the work environment can mediate the relationship between the influence of leadership style on lecturer performance. The results of this study are in line with research conducted by Narasuci et al., (2018). Lecturers will try to improve cooperation and be brave in making decisions for both personal and institutional interests. With the right leadership style starting from planning to evaluating the work activities of lecturers and supported by a strong relationship between leaders and lecturers, it will further encourage the achievement of the tri dharma of higher education following the direction of the leadership optimally. This result positively impacts the progress and improvement of STAI Madiun's accreditation in providing a more comprehensive education at the tertiary level.

\section{Effect of Information Technology Support on Lecturer Performance Mediated by Work Environment}

Based on the test results show that leadership style has a positive and significant effect on lecturer performance. The results of this study are in line with the research conducted by Naujokaitiene et al., (2015). When the availability of updated and renewable technological work tools, both for lecturers in organizing the tri dharma of higher education or for students participating in lecture activities at STAI Madiun supported by adequate campus facilities, harmonious relationships between lecturers and students, will make lecturers improve their performance in supporting the achievement of institutional goals.

\section{Implication and Conclusion}

Based on the results of the discussion in the study, it can be concluded that the variables of leadership style, information technology support and work environment have a significant effect on the performance of lecturers at private universities in Semarang. Furthermore, the work environment variable can mediate the relationship between the influence of leadership style and information technology support on the performance of lecturers at private universities in Semarang.

The limitations of this research include the factors that affect the performance of lecturers are limited to leadership style, information technology support, and the environment only so that the scope is not wide enough to be taken into consideration in making human resource management decisions and the scope of research is limited to one place and time. The study is limited, so the results cannot be compared with other similar universities in comparing their performance during distance learning.

The managerial implication in this research is that the leaders of private universities in Semarang need to consider more seriously improving the performance of existing lecturers by having good conceptual and innovation skills, explaining and directing the tasks given, and directly monitoring the performance of lecturers while working so that lecturers feel more explicit and more focused in implementing distance learning. Leaders of private universities in Semarang need to provide adequate technological infrastructure so that lecturers can carry out distance learning more effectively and efficiently. Besides that, information technology support also supports lecturers' performance in fulfilling the tri dharma of higher education. This policy can be a longterm strategy so that private universities in Semarang are increasingly able to adapt to the times and can increase their competitiveness in the education industry. The availability of adequate information technology support is a novelty and selling point for an educational institution.

\section{References}

Anyango, C. A. (2015). Effects of Leadership Styles on Employee Performance. Human Resource, 1, 92.

Aropah, V. D., Sarma, M., and Sumertajaya, I. M. (2020). Factors Affecting Employee Performance during Work from Home. International Research Journal of Business Studies, 13(2), 201-214. 
Babatunde, O. (2015). The Impact of Leadership Style on Employee's Performance in an Organization. Public Policy and Administration Research, 5(1), 193-206.

Birbirsa, Z. A., and Lakew, D. M. (2020). The Effect of Leadership Style on the Job Satisfaction of Micro and Small Enterprises. International Research Journal of Business Studies, 13(1), 27-32. https://doi.org/10.21632/irjbs.13.1.27-32

Bos-Nehles, A., Renkema, M., and Janssen, M. (2017). HRM and innovative work behaviour: a systematic literature review. Personnel Review, 46(7), 1228-1253. https://doi.org/10.1108/PR-09-2016-0257

Bozkurt, A., Akgun-Ozbek, E., Yilmazel, S., Erdogdu, E., Ucar, H., Guler, E., Sezgin, S., Karadeniz, A., Sen-Ersoy, N., Goksel-Canbek, N., Dincer, G. D., Ari, S., and Aydin, C. H. (2015). Trends in distance education research: A content analysis of journals 2009-2013. International Review of Research in Open and Distance Learning, 16(1), 330-363. https://doi.org/10.19173/irrodl.v16i1.1953

Bungai, J., and Perdana, I. (2018). Evaluation of Performance Lecturer on Implementing Tridharma College. Indonesian Journal of Educational Review, 5(1), 174-182. http://journal.unj.ac.id/unj/index.php/ijer

El Firdoussi, S., Lachgar, M., Kabaili, H., Rochdi, A., Goujdami, D., and El Firdoussi, L. (2020). Assessing Distance Learning in Higher Education during the COVID-19 Pandemic. Education Research International, 2(1), 1-13. https://doi.org/10.1155/2020/8890633

Fawehinmi, O., Yahya, K. K., Yusliza, M. Y., and Muhammad, Z. (2020). Dataset On The Antecedents Of Career Adaptability Among Undergraduate Students In Malaysia. Data in Brief, 32(106211), 1-5. https://doi.org/10.1016/j.dib.2020.106211

Frye, W. D., Kang, S., Huh, C., and Lee, M. J. (MJ). (2019). What factors influence Generation Y's employee retention in the hospitality industry?: An internal marketing approach. International Journal of Hospitality Management, July, 102352. https://doi.org/10.1016/j.ijhm.2019.102352

Hadiantini, R., Pandia, S. P., and Kaburuan, E. R. (2017). Lecturer Performance Factors in Private Universities in Bandung City. International Journal of Human Resource Studies, 7(4), 231-239. https://doi.org/10.5296/ijhrs.v7i4.12079

Hamid, R., Sentryo, I., and Hasan, S. (2020). Online learning and its problems in the Covid-19 emergency period. Jurnal Prima Edukasia, 8(1), 86-95. https://doi.org/10.21831/jpe.v8i1.32165

Handayani, S. (2019). Effect of Motivation on Lecturer Performance at the Institute of Social and Political Sciences (IISIP), Yapis Biak. Jurnal Ilmiah Ilmu Administrasi Publik, 9(1), 28. https://doi.org/10.26858/jiap.v9i1.9317

Harni, B. (2018). A Role Of Emotional Intelligence Improving Lecturer Performance. JHSS Journal of Humanities and Social Studies), 2(1), 22-25. https://doi.org/10.33751/jhss.v2i1.817

Huang, Y. (2020). Research on Online Education in the Midst of the COVID-19 Pandemic. Journal of Advances in Education Research, 5(2), 125-137. https://doi.org/10.22606/jaer.2020.52005

Kumar, V., Lai, K. K., Chang, Y. H., Bhatt, P. C., and Su, F. P. (2021). A Structural Analysis Approach to Identify Technology Innovation and Evolution Path: A Case of M-Payment Technology Ecosystem. Journal of Knowledge Management, 25(2), 477-499. https://doi.org/10.1108/JKM-01-2020-0080

Mulyaningsih, Mulyanti, D., Djogo, O., Ismawanti, R., Mulyanto, A. I., and Suhartono. (2020). A Survey Study Of Lecturer's Performance About Work From Home During The Pandemic Of Covid-19. International Journal of Pharmacentical Research, 12(4), 3867-3872. https://doi.org/10.31838/ijpr/2020.12.04.529 
Na-nan, K., Joungtrakul, J., and Dhienhirun, A. (2018). The Influence of Perceived Organizational Support and Work Adjustment on the Employee Performance of Expatriate Teachers in. Modern Applied Science, 12(3), 105-116. https://doi.org/10.5539/mas.v12n3p105

Narasuci, W., Setiawan, M., and Noermijati. (2018). Effect Of Work Environment On Lecturer Performance Mediated By Work Motivation And Job Satisfaction. Journal of Applied Management, 16(4), 645-653.

Naujokaitiene, J., Tereseviciene, M., and Zydziunaite, V. (2015). Organizational support for employee engagement in technology-enhanced learning. SAGE Open, 5(4). https://doi.org/10.1177/2158244015607585

Pradhan, R. K., and Jena, L. K. (2017). Employee Performance at Workplace: Conceptual Model and Empirical Validation. Business Perspectives and Research, 5(1), 69-85. https://doi.org/10.1177/2278533716671630

Purwanto, A., Asbari, M., Fahlevi, M., and Mufid, A. (2020). Impact of Work From Home (WFH) on Indonesian Teachers Performance During the Covid-19 Pandemic $\square$ : An Exploratory Study Impact of Work From Home (WFH) on Indonesian Teachers Performance During the Covid-19 Pandemic $\square$ : An Exploratory Study. International Journal of Advanced Science and Technology, 29(5), 6235-6244.

Putra, F. I. F. S., Budiantoro, R. A., Luxfiati, B. A., and Widawati, M. W. (2020). Consumer Satisfaction Behavior Bought Chinese Smartphone In The Official Store And Black Market In Soloraya. Jurnal Aplikasi Manajemen, 18(3), 588-596. https://doi.org/http://dx.doi. org/10.21776/ub.jam.2020. 018.03.19

Soetikno, Y. J. (2017). The Influence Of Work Environment And Organizational Culture On Work Satisfaction And Lecturers Performance At The Schools Of Management Information And Computer In. International Journal of Scientific \& Technology Research, 6(4), 132-136.

Sukirno. (2020). Dataset of Lecturer Performance Appraisel. Data in Brief, 32(106161), 1-15. https://doi.org/10.1016/j.dib.2020.106161

Sun, L. (2019). Perceived Organizational Support: A Literature Review. International Journal of Human Resource Studies, 9(3), 155. https://doi.org/10.5296/ijhrs.v9i3.15102

Tahir, M., Haming, M., Rusjdin, and Bijaang, J. (2018). Organizational Communication Effect On Lecturer Performance In Muhammadiyah University Of Makassar. The International Journal of Engineering and Science (IJES), 6(12), 19-27. https://doi.org/10.31227/osf.io/9j5k8

Wilson, K. G. (2016). Impact of Work Environment on Academic Staff Job Performance: Case of a Uganda University Impact of Work Environment on Academic Staff Job Performance: Case of a Uganda University. International Journal of Advances in Management and Economics, 4(4), 95-103.

Yulia, H. (2020). Online Learning to Prevent the Spread of Pandemic Corona Virus in Indonesia. ETERNAL (English Teaching Journal), 11(1), 48-56. https://doi.org/10.26877/eternal.v11i1.6068 